\title{
JNPH
}

Volume 5 No. 2 (Desember 2017)

(C) The Author(s) 2017

\section{APLIKASI TEORI MODEL CALISTA ROY DALAM PEMBERIAN ASUHAN KEPERAWATAN PADA NY. S DENGAN KISTA OVARIUM DI SUKAMAJU KOTA BENGKULU}

\author{
APPLICATION OF THE THEORY OF CALISTA ROY MODEL IN GIVING NURSING \\ ASSISTANCE IN NY. S WITH OVARIAN CYSTS IN SUKAMAJU BENGKULU CITY
}

\author{
ITA SUSIANTI \\ UPTD PUSKESMAS PADANG SERAI KOTA BENGKULU \\ Email: dwilestariwiji@gmail.com
}

\begin{abstract}
ABSTRAK
Kista ovarium dapat mengganggu pembentukan sel telur karena peningkatan hormon androgen sehingga mengganggu pematangan folikel, dengan demikian saat terjadi ovulasi tidak berisi sel telur (Ricci, 2009). Karena ovulasi tidak mengandung sel telur, maka perempuan cenderung menjadi infertil (Ricci, 2009). Teori adaptasi Calista Roy merupakan model keperawatan yang menguraikan bagaimana individu mampu meningkatkan kesehatan dengan cara mempertahankan perilaku adaptasi serta mampu merubah perilaku yang inadaptif. Penerapan teori akan membantu seseorang untuk beradaptasi terhadap perubahan kebutuhan fisiologis, konsep diri, fungsi peran, dan interdependensi selama sehat dan sakit (Tomey \& Alligood, 2010). Pendekatan asuhan keperawatan dengan menggunakan pendekatan teori adaptasi Calista Roy dipandang sangat ideal untuk diterapkan dalam memberikan pelayanan asuhan keperawatan profesional terutama pada pasien dengan penyakit kista ovarium yang memerlukan adaptasi panjang terhadap perubahan status kesehatannya Jenis studi kasus ini adalah studi kasus Kista Ovarium dengan aplikasi teori Calista Roy dengan menggunakan metode deskriptif yaitu suatu metode yang dilakukan dengan tujuan utama untuk membuat gambaran atau deskripsi tentang suatu keadaan secara obyektif dan memusatkan perhatian pada objek tertentu. Keefektifan aplikasi teori Roy pada pelaksanaan asuhan keperawatan pada pasien kista ovarium yaitu dapat meningkatkan perilaku yang baik pada penderita kista ovarium dalam melakukan upaya penanganan dan upaya pencegahan terhadap terjadinya kista ovarium. Sehingga dapat disimpulkan bahwa teori Roy dapat meningkatkan kesehatan pasien secara optimal baik jangka pendek maupun jangka panjang. Kepada pihak pelayanan kesehatan diharapkan dapat menerapkan aplikasi keperawatan pada pasien dengan aplikasi yang ada seperti dengan menggunakan aplikasi teori Calista Roy, ataupun dengan aplikasi teori lainnya yang sesuai dengan keadaan pasien dan teori yang ada sehingga didapatkan hasil perawatan yang optimal.
\end{abstract}

Kata Kunci: kista ovarium, teori calista roy

\begin{abstract}
Ovarian cysts can interfere with the formation of the eggs because of the increase in androgen hormones that interfere with follicular maturation, thus when ovulation does not contain egg cells (Ricci, 2009). Because ovulation does not contain eggs, women tend to become infertile (Ricci, 2009). Calista Roy's adaptation theory is a nursing model that describes how individuals
\end{abstract}


are able to improve health by maintaining adaptation behaviors and able to change adaptive behaviors. Application of theory will help one to adapt to changes in physiological needs, selfconcept, role function, and interdependence during health and illness (Tomey \& Alligood, 2010). The approach of nursing care using the Calista Roy adaptation approach is considered to be ideal for application in providing professional nursing care especially in patients with ovarian cyst disease requiring long adaptation to health status change. This case study type is case study of Ovarian Cyst with Calista Roy theory application with using descriptive method is a method that is done with the main purpose to create a picture or description of a situation objectively and focus on a particular object. The effectiveness of Roy's theory application on the implementation of nursing care in patients with ovarian cysts is that it can improve good behavior in patients with ovarian cysts in making efforts and prevention efforts against the occurrence of ovarian cysts. So it can be concluded that the theory Roy can improve patient health optimally both short and long term. To the health service is expected to apply nursing applications in patients with existing applications such as using the application of Calista Roy theory, or with other theoretical applications in accordance with the state of the patient and the existing theory to obtain optimal care results.

Keywords: ovarian cyst, calista roy theory

\section{PENDAHULUAN}

Kesehatan adalah keadaan sejahtera dari badan, jiwa, dan sosial yang memungkinkan setiap orang hidup produktif secara sosial dan ekonomis. Pembangunan kesehatan bertujuan untuk meningkatkan kesadaran, kemauan dan kemampuan hidup sehat bagi setiap orang agar terwujud derajat kesehatan masyarakat yang setinggi-tingginya. Kegiatan untuk meningkatkan kesehatan (promotif), mencegah penyakit (preventif), terapi (kuratif) maupun pemulihan kesehatan (rehabilitatif) adalah upaya kesehatan masyarakat (Depkes RI, 2011).

Kista ovarium merupakan salah satu bentuk penyakit repoduksi yang banyak menyerang wanita. Kista atau tumor merupakan bentuk gangguan yang bisa dikatakan adanya pertumbuhan sel-sel otot polos pada ovarium yang jinak. Walaupun demikian tidak menutup kemungkinan untuk menjadi tumor ganas atau kanker. Perjalanan penyakit ini sering disebut sillent killer atau secara diam diam menyebabkan banyak wanita yang tidak menyadari bahwa dirinya sudah terserang kista ovarium dan hanya mengetahui pada saat kista sudah dapat teraba dari luar atau membesar ( Depkes RI, 2011).

The American Cancer Society memperkirakan bahwa pada tahun 2014, sekitar 21.980 kasus baru kanker ovarium akan didiagnosis dan 14.270 wanita akan meninggal karena kanker ovarium di Amerika Serikat. Angka kejadian kista ovarium tertinggi ditemukan pada negara maju, dengan rata-rata 10 per 100.000 , kecuali di Jepang (6,5 per 100.000). Insiden di Amerika Selatan $(7,7$ per 100.000$)$ relatif tinggi bila dibandingkan dengan angka kejadian di Asia dan Afrika (WHO,2015).

Angka kejadian kista ovarium di Indonesia belum diketahui dengan pasti karena pencatatan dan pelaporan yang kurang baik. Sebagai gambaran Rumah Sakit yang terdeteksi kista ovarium terbesar di indonesia antarnya di RSU Dharmais, ditemukan kirakira 300 pasien setiap tahun, RSUD Cipto Mangunkusumo terdata pada tahun 2008 ada 428 kasus pasien kista endometriosis setiap tahun. Sedangkan pada tahun 2009 terjadi peningkatan tajam di RSUD Cipto Mangunkusumo terdata 768 kasus pasien kista ovarium dan $25 \%$ diantaranya meninggal dunia $70 \%$ diantaranya adalah wanita karir yang telah berumah tangga. Kista ovarium menempati urutan pertama pada kasus terbesar di RSUD Cipto Mangunkusumo dan RSU Dharmais menempati urutan ke dua dari seluruh Rumah Sakit terbesar yang ada di indonesia (Nasdaldy, 2009). 
Di sumatera angka kejadian kista ovarium belum diketahui dengan pasti akan tetapi sebagai gambaran terdapat jumlah seluruh wilayah sumatera dengan penderita kista ovarium tahun 2008-2009 sebanyak 47orang (Safitri, 2010). Sedangkan pada tahun 2010-2015 terjadi peningkatan kasus penderita kista ovarium sebanyak 116 kasus (Dumaris 2016). Provinsi Bengkulubukan salah satu 7 provinsi daerah endemis kista ovarium namun merupakan provinsi yang banyak ditemukan kasus baru kista ovarium di Sumatera. Berdasarkan laporan diketahui bahwa jumlah kasus kista ovarium yang ditemukan meningkat dari tahun ke tahun. Pada tahun 2014 ditemukan 35 kasus dan tahun 2015 ditemukan 47 kasus lagi sedangkan pada tahun 2016 meningkat menjadi 89 kasus kista ovarium (Provinsi Bengkulu, 2016).

Penyebab penyakit kista ovarium sebagian merupakan kista fungsional, bersifat jinak dan dapat menghilang dengan sendirinya, sebagian memerlukan tindakan khusus antara lain pengangkatan dengan cara operasi (BCCOG, 2011). Penyakit kista ovarium dapat menyebabkan komplikasi antara lain indung telur membesar dan menjadi lebih berat dan memicu terjadinya robekan (rupture), terpelintir (torsion) yang menyebabkan nyeri hebat, dysplasia dan sepsis (Salehpour et-al, 2013).

Kista ovarium dapat mengganggu pembentukan seltelur karena peningkatan hormon androgen sehingga mengganggu pematangan folikel, dengandemikian saat terjadi ovulasi tidak berisi sel telur (Ricci, 2009). Karena ovulasi tidak mengandung sel telur, maka perempuan cenderung menjadi infertil (Ricci, 2009). Kista ovarium menimbulkan beragam manifestasi klinis pada pasien. Manifestasi klinis yang terjadi dapat berupa ketidak nyamanan pada abdomen, sulit buang air kecil, nyeri panggul, dan nyeri saat senggama serta gangguan menstruasi. Adanya gangguan menstruasi ini menyebabkan masyarakat berpendapat bahwa wanita yang mengalami kista ovarium akan mengalami kemandulan (infertilitas). Hal ini dapat menimbulkan kecemasan pada pasiennya (Sungkar, 2015).

Penanganan infertil pada perempuan salah satunya dengan menggunakan obat penyubur (fertility drugs) sementara obat-obat penyubur telah diidentifikasi menjadi faktor risiko terjadinya neoplasma ovarium (Denschlag, 2010). Neoplasma ovarium termasuk dalam kelompok tumor epithelial, kebanyakan bersifat jinak dan hanya sebagian kecil yang bersifat ganas, neoplasma ovarium ganas lebih mematikan dibandingkan dengan jenis kanker ginekologi lainnya (Sallinen etal, 2014). Neoplasma ovarium selain mempengaruhi kesuburan seorang perempuan, juga dapat menyebabkan terjadinya gangguan menstruasi, tumbuh bulu-bulu halus pada wajah (hirsutism), kulit menipis, terdapat echymosis, centraladiposity, buffalo hump, penumpukan lemak pada supraclavicula dan hipertensi berat. Untuk mengatasi permasalahan tersebut dapat dilakukan dengan oophorectomy atau pengangkatan ovarium (Sallinen et-al, 2014, Yuan et-al, 2014).

Pengangkatan ovarium yang dilakukan dapat berpengaruh terhadap pembentukan hormon estrogen dan progesteron dan bila pengangkatan dilakukan sebelum pubertas maka organ-organ yang pematangannya dipengaruhi oleh estrogen dan progesteron akan mengalami gangguan. Estrogen juga berfungsi menjaga kekuatan tulang, berkurangnya estrogen akan menyebabkan penarikan kalsium dari tulang yang berakibat pada osteoporosis (Ricci, 2009). Kista yang sudah diangkat dapat tumbuh kembali ditempat yang sama dan menyebar ketempat lainnya. Seseorangyang mengalami hirsutism, gangguan menstruasi, hipertensi, peningkatan cortisol dan androgen merupakan tanda awal terjadinya kekambuhan (recurrence) setelah dilakukan pengangkatan kista (Yuan et-al, 2014).

Permasalahan yang terjadi pada fisik seseorang akan berpengaruh pada kondisi psikologi, demikian keluhan yang dirasakan oleh penderita neoplasma meliputi gejala fisik seperti nyeri dan pembesaran massa tumor, 
psikologi seperti kecemasan, gangguan body. mempengaruhi satu dengan yang lainnya (Dodd et-al, 2011, Kim et-al, 2005). Mengingat permasalahan yang dialami penderita tumor meliputi fisik dan psikologi maka dalam penangananpun harus merupakan satu kesatuan. Hakekat asuhan keperawatan adalah memberikan asuhan kepada pasien secara holistik dan komprehensif meliputi bio, psiko, sosial dan spiritual (Perry \& Potter, 2009). Perawat dalam memberikan asuhan keperawatan agar sesuai dengan permasalahan yang ada, maka perlu dipilih suatu teori pendekatan asuhan keperawatan.

Teori adaptasi Calista Roy merupakan model keperawatan yang menguraikan bagaimana individu mampu meningkatkan kesehatan dengan cara mempertahankan perilaku adaptasi serta mampu merubah perilaku yang inadaptif. Penerapan teori akan membantu seseorang untuk beradaptasi terhadap perubahan kebutuhan fisiologis, konsep diri, fungsi peran, dan interdependensi selama sehat dan sakit (Tomey \& Alligood, 2010). Pendekatan asuhan keperawatan dengan menggunakan pendekatan teori adaptasi Calista Roy dipandang sangat ideal untuk diterapkan dalam memberikan pelayanan asuhan keperawatan profesional terutama pada pasien dengan penyakit kista ovarium yang memerlukan adaptasi panjang terhadap perubahan status kesehatannya.

Teori adaptasi Roy menitikberatkan pendekatan pada tiga hal meliputi stimulus fokal yaitu stimulus atau rangsangan yang berasal dari dalam individu maupun dari luar individu dan harus dihadapi secara langsung pada saat itu juga. Stimulus kontekstual adalah semua stimulus yang berpengaruh terhadap stimulus fokal berasal dari lingkungan sekitar, sedangkan stimulus residual merupakan faktor yang berasal dari lingkungan sekitar yang dapat berpengaruh secara tidak langsung pada individu (Tomey \& Alligood, 2010). Melihat hal di atas pada survei pendahuluan yang dilakukan di UPTD Puskesmas Padang Serai Bengkulu dari data pencatatan dengan pasien tindak lanjut kasus kista ovarium terdapat data tahun 2014 sejumlah 3 orang dan pada tahun 2015 adalah sebanyak 5 orang, sedangkan pada tahun 2016 data kasus dengan tindak lanjut kista ovarium sebanyak 9 orang yang berkunjung dan dilakukan survei sejumlah wilayah UPTD Puskesmas Padang serai Bengkulu. Hal ini terjadi peningkatan adanya kurang kesadaran pengetahuan masyarakat terutama bagi wanita yang sudah terkena kista ovarium ataupun yang belum mengetahuinya.

\section{METODE PENELITIAN}

Jenis studi kasus ini adalah studi kasus kista ovarium dengan aplikasi teori Calista Roy dengan menggunakan metode deskriptif yaitu suatu metode yang dilakukan dengan tujuan utama untuk membuat gambaran atau deskripsi tentang suatu keadaan secara obyektif dan memusatkan perhatian pada objek tertentu (Notoatmojo, 2010).

\section{HASIL PENELITIAN}

Aplikasi teori Calista Roy dalam pemberian asuhan keperawatan pada $\mathrm{Ny} \mathrm{S}$ dengan kista ovarium. Dalam Bab ini, penulis akan membahas meliputi segi pengkajian, diagnosa, perencanaan keperawatan, implementasi keperawatan, dan evaluasi keperawatan mengenai kasus yang penulis angkat.

\section{Pengkajian}

Pengkajian merupakan tahap awal dari proses keperawatan dan merupakan suatu proses pengumpulan data yang sistematis dari berbagai sumber untuk mengevaluasi dan mengidentifikasi status kesehatan klien. Pada saat pengumpulan data, penulis tidak menemukan banyak kendala karena Ny. S dan keluarga sangat kooperatif yang ditunjang dengan terbinanya kepercayaan antara penulis dengan Ny. S beserta keluarga. Ny. S juga memberikan informasi yang lengkap dan jelas sesuai dengan pertanyaan yang diajukan penulis. Dalam pengkajian keperawatan ini difokuskan pada teori Calista Roy pada saat 
pengkajian didapatkan data hasil: Nadi: 84x /menit, Suhu: $36,2^{0} \mathrm{C}$, Pernafasan: 20x /menit, Tensi darah: $140 / 90$, konjunctiva anemis, klien sering merasa pusing, BU 5x /menit, terdapat pengeluaran darah pervaginam, bentuk abdomen asimetris, terdapat benjolan di abdomen dekstra, klien mengeluh nyeri pada perut bagian bawah, nyeri dirasakan klien seperti melilit - lilit, panas pada bokong selama \pm 4 jam secara terus menerus dengan skala \pm 10 (sakit sekali), klien mengatasinya dengan mengelus - elus bokongnya.

Menurut pengembangan teori Roy pengkajian dilakukan yaitu oksigenasi: menggambarkan pola penggunaan oksigen berhubungan dengan respirasi, dan sirkulasi, Nutrisi: menggambarkan pola penggunaan nutrisi untuk memperbaiki kondisi tubuh dan perkembangan, eliminasi: menggambarkan pola eliminasi, aktivitas dan istirahat: menggambarkan pola fisiologis kulit, rasa/senses: menggambarkan fungsi sensoris perceptual berhubungan dengan panca indra, cairan dan elektrolit: menggambarkan pola fisiologis penggunaan cairan dan elektrolit, fungsi neurologis: menggambarkan pola kontrol neurologis, pengaturan dan intelektual, fungsi endokrin: menggambarkan pola kontrol dan pengaturan termasuk respon stress dan system reproduksi, pengkajian konsep diri, pengkajian fungsi peran (sosial) dan pengkajian interdependensi.

\section{Diagnosa Keperawatan}

Diagnosa keperawatan memberikan
dasar untuk pemilihan intervensi keperawatan, untuk mencapai hasil yang merupakan tanggung jawab perawat. Pada asuhan keperawatan Ny. S dengan kista ovarium ditemukan diagnosa keperawatan. Sedangkan masalah - masalah keperawatan yang muncul pada klien $\mathrm{Ny}$. S pada saat melakukan asuhan keperawatan antara lain :gangguan rasa nyaman nyeri berhubungan dengan adanya masa di perut bawah, gangguan volume cairan kurang dari kebutuhan tubuh berhubungan dengan adanya perdarahan, gangguan nutrisi kurang dari kebutuhan tubuh berhubungan dengan intake tidak adekuat.

Roy mendefenisikan untuk menyusun diagnosa keperawatan, menggunakan tipologi diagnosa yang dikembangkan oleh roy dan berhubungan dengan 4 mode adaptif. Jadi peningkatan adaptasi dalam tiap 4 cara menyesuaikan diri yaitu: fungsi fisiologi, konsep diri, fungsi peran dan interpendensi. Harapan terhadap peningkatan integritas adaptasi dan berkontribusi terhadap kesehatan manusia, kualitas hidup dan kematian yang bermanfaat. Tujuan keperawatan diraih ketika stimulus vokal berada didalam suatu area tingkatan adaptasi manusia, dan ketika stimulus vokal tersebut tidak ada dalam area, manusia dapat membuat suatu penyesuaian diri atau respon efektif.

\section{Intervensi}

Dalam penyusunan perencanaan keperawatan, penulis melakukan sesuai dengan diagnosa yang telah diprioritaskan yaitu komponen tujuan, kriteria dan rencana keperawatan. Dalam menentukan intervensi keperawatan pada pasien penulis menyusun sesuai dengan apa yang dibutuhkan pasien, dimodifikasi sesuai kondisi, usia, emosi, status sosial, kebudayaan, dan kapasitas intelektual pasien. Pada penetapan tujuan dan rencana tindakan perawat akan memfasilitasi Ny. S dalam melakukan penanganan pada masalah kista ovarium yang meliputi:Gangguan Rasa nyaman nyeri berhubungan dengan adanya masa di perut bawah

Gangguan volume cairan kurang dari kebutuhan tubuh berhubungan dengan adanya perdarahan, gangguan nutrisi kurang dari kebutuhan tubuh berhubungan dengan intake tidak adekuat.

Menurut Roy intervensi keperawatan adalah suatu perencanaan dengan tujuan merubah atau memanipulasi simulasi fokal, kontekstual, dan residual. Pelaksanaannya juga ditujukan kemampuan klien dalam koping secara luas, supaya stimulus secara 
keseluruhan dapat terjadi pada klien, sehingga total stimuli berkurang dan kemampuan adaptasi meningkat. Tujuan intervensi keperawatan adalah pencapaian kondisi yang optimal, dengan menggunakan koping yang konstruktif. Tujuan jangka panjang harus dapat menggambarkan penyelesaian masalah adaptif dan ketersediaan energi untuk memenuhi kebutuhan tersebut (mempertahankan, pertumbuhan, reproduksi). Tujuan jangka pendek mengidentifikasi harapan perilaku klien setelah manipulasi stimulus fokal, kontekstual dan residual.

\section{PEMBAHASAN}

\section{Implementasi}

Pada pelaksanaan tindakan keperawatan pada klien seluruh rencana tindakan dapat diaplikasikan dengan baik dan tidak ada masalah yang berarti. Karena banyak hal yang mendukung dalam pelaksanaan asuhan keperawatan ini. Adapun faktor yang mendukung implementasi ini adalah: adanya keinginan pasien untuk sembuh sehingga pasien menerima saran dan anjuran perawat, adanya keinginan pasien dan untuk mengetahui penanganan penyakitnya. Semua masalah yang ada penulis dapat melaksanakannya dan dari tindakan yang telah direncanakan dan diimplementasikan atas persetujuan pasien serta berdasarkan standar praktek keperawatan. Implementasi keperawatan direncanakan dengan tujuan merubah atau memanipulasi fokal, kontekstual, dam residual stimuli dan juga memperluas kemampuan koping seseorang pada zona adaptasi sehingga total stimuli berkurang dan kemampuan adaptasi meningkat (Asmadi, 2008)

$$
\text { Roy (1983) menggambarkan }
$$

keperawatan sebagai disiplin ilmu dan praktek. Sebagai ilmu keperawatan, mengobservasi, mengklasifikasikan dan menghubungkan proses yang secara positif berpengaruh pada status kesehatan. Sebagai disiplin, praktek, keperawatan menggunakan pendekatan pengetahuan untuk menyediakan pelayanan pada orang - orang. Lebih spesifik dia mendefinisikan keperawatan sebagai ilmu dan praktek dari peningkatan adaptasi untuk meningkatkan kesehatan sebagai tujuan untuk mempengaruhi kesehatan secara positif. Keperawatan meningkatkan adaptasi individu dan kelompok dalam situasi yang berkaitan dengan kesehatan, jadi model adaptasi keperawatan menggambarkan lebih spesifik perkembangan ilmu keperawatan dan praktek keperawatan yang berdasarkan ilmu keperawatan tersebut. Dalam model tersebut, keperawatan terdiri dari tujuan keperawatan dan aktivitas keperawatan.

\section{Evaluasi Keperawatan}

Evaluasi keperawatan adalah proses keperawatan mengukur respon klien terhadap tindakan keperawatan dan kemajuan klien ke arah pencapaian tujuan (potter dan perry 2006). Dari diagnosa yang penulis temukan, semua sesuai dengan masalah yang dialami Ny. S pada saat penulis melakukan studi kasus kepada Ny. S semua intervensi sudah mencapai kriteria hasil. Pasien mampu melakukan hidup sehat dan melakukan pencegahan kista ovarium mampu berperilaku yang baik dalam penanganan yang baik terhadap penyakit yang dideritanya dan tidak ada tanda infeksi serta kebutuhan tidur pasien terpenuhi.

Menurut Roy penilaian terakhir dari proses keperawatan berdasarkan tujuan keperawatan yang ditetapkan. Penetapan keberhasilan suatu asuhan keperawatan didasarkan pada perubahan perilaku dari kriteria hasil yang ditetapkan, yaitu terjadinya adaptasi pada individu (Asmadi, 2008).

\section{Keefektifan Teori Roy}

Keefektifan aplikasi teori Roy pada pelaksanaan asuhan keperawatan pada pasien kista ovarium yaitu dapat meningkatkan perilaku yang baik pada penderita kista ovarium dalam melakukan upaya penanganan dan upaya pencegahan terhadap terjadinya kista ovarium. Sehingga dapat disimpulkan 
bahwa teori Roy dapat meningkatkan kesehatan pasien secara optimal baik jangka pendek maupun jangka panjang. Keunggulan Roy dalam penatalaksanaan kasus ini adalah dimana pada pengkajian mencakup semua pada aspek fisiologis maupun aspek psikologis dan faktor sistem pendukung terjadinya masalah pada pasien. Selain itu juga pada hasil yang didapat pada asuhan keperawatan ini sangat efektis sebagai upaya meningkatkan perilaku pasien dalam melakukan penanganan pada penyakitnya dan upaya jangka panjang dalam mencegah terjadinya penyakit tersebut berulang.

Menurut Roy, melalui pengelolaan faktor-faktor stimulus, pencetus tidak efektifnya perilaku diubah atau meningkatkan kemampuan individu untuk mengatasi masalah. Itu adalah memperlebar penyesuaian diri. Jadi stimulus akan jatuh ke area yang dibangun oleh tingkat penyesuaian diri manusia dan perilaku adaptif akan terjadi. Intervensi keperawatan berikutnya, mengevaluasi hasil akhir perilaku dan memodifikasi pendekatan-pendekatan keperawatan sesuai kebutuhan. Ini harus dicatat bahwa dalam model manusia dihormati sebagai individu yang berpartisipasi aktif dalam perawatan dirinya. Tujuan disusun berdasarkan tujuan yang saling menguntungkan.

\section{Kelemahan aplikasi teori dalam menyelesaikan masalah yang diangkat}

Kelemahan dari model adaptasi Roy ini adalah terletak pada sasarannya. Model adaptasi Roy ini hanya berfokus pada proses adaptasi pasien dan bagaimana pemecahan masalah pasien dengan menggunakan proses keperawatan dan tidak menjelaskan bagaimana sikap dan perilaku cara merawat (caring) pada pasien. Sehingga seorang perawat yang tidak mempunyai perilaku caring ini akan menjadi stressor bagi pasiennya.

\section{KESIMPULAN}

Intervensi dan implementasi yang ditegakkan oleh penulis sudah sesuai dengan teori Calista Roy sesuai diagnosa yang ditegakkan, implementasi dilakukan sesuai dengan rencana keperawatan yang disusun, disertai respon hasil dari pasien, tahap evaluasi dari diagnosa keperawatan yang penulis implementasikan selama 4 hari berhasil dilakukan, teori Model Calista Roy efektif di aplikasikan pada pasien dengan kasus kista ovarium.

\section{SARAN}

Kepada pihak pelayanan kesehatan diharapkan dapat menerapkan aplikasi keperawatan pada pasien dengan aplikasi yang ada seperti dengan menggunakan aplikasi teori calista roy, ataupun dengan aplikasi teori lainnya yang sesuai dengan keadaan pasien dan teori yang ada sehingga didapatkan hasil perawatan yang optimal.

\section{DAFTAR PUSTAKA}

Agusfarly. 2013. Penyakit Kandungan, Jakarta : Pustaka Populer Obor

Asmadi. 2008. Konsep Dasar Keperawatan, Jakarta ; Buku Kedokteran EGC

BCCOG. 2011. Asuhan Keperawatan, Jakarta : Salemba

Chyantia. 2009. Pahami Kista Anda Akan Terbebaskan, Yogyakarta : Maximus

Cunningham. 2009. Penyakit Kandungan, Jakarta : Pustaka Populer Obor

.2014. Ilmu Penyakit Reproduksi, Jakarta

: Pustaka Populer Obor

Denschlag. 2010. Kista Ovarium, Jakarta : IDI

Depkes RI. 2011. Rencana Stategis Kementrian Kesehatan 2010-2014, Jakarta

Dinkes . 2016. Profil Laporan Penyakit Kista Ovarium, Dinas Kesehatan

Doadd et-al. 2011. Manajemen Asuhan Keperawatan, Jakarta : Salemba Medika

Dumaris. 2016. Jurnal Kista Ovarium. 
Diunduh dari Http://mail.yahoo.com. Diakses tanggal 20 Juli 2017

Djuanda. 2013. Buku Ajar Asuhan Keperawatan, Jakarta : Andi Offlet

Joedosepoetro. 2005. Solusi Problem Persalinan, Jakarta : Puspa Suara

Jocoeb. 2010. Buku ajar Ilmu Bedah, Jakarta : ECG

Kusuma. 2008. Ilmu penyakit Kulit dan Kelamin, Jakarta : KAUI

Kim et al. 2005. Prosedur Penelitian Suatu Pendekatan Praktis, Jakarta : Rineka Cipta

Maharani. 2008. Penyakit Kulit, Jakarta : FKM UI

Nasdaldy. 2009. Aplikasi dan Konsep Keperawatan, Jakarta : Cipta Pustaka

Nursalam. 2008. Proses dan Dokumentasi Keperawatan, Jakarta : Salemba Medika

Nusratuddin. 2009. Buku Saku Kumpulan Penyakit Dalam, Bandung : Pustaka

Notoatmodjo. 2010. Motode Penelitian Kesehatan, Jakarta : Rineka Cipta

Perry dan Potter. 2009. Buku ajar fundamental Keperawatan Volume 2. Edisi 4, Jakarta : EGC

Provinsi Bengkulu. 2016. Profil Laporan Penyakit Kista Ovarium, Dinas Kesehatan

Ricci. 2009. Hapami Penyakit Kista Ovarium, Jakarta; Andi Offlet

Sallinen et-al. 2014. Buku Panduan Pelayanan Kesehatan, Jakarta : Yayasan Bina Pustaka

Sarwono. 2008. Manajemen Obstetri Asuhan Keperawatan, Jakarta : Mitra Cendikia

Saleh pour et-al. 2013. Konseptual Asuhan Keperawatan Obstetri, Jakarta : Cipta Pustaka

Setiati. 2009. Buku Asuhan Keperawatan, Jogyakarta : Mitra Cendikia

Sungkar. 2015. Dermakologi Praktis, Jakarta : Hipokrates

Tomey dan alligood. 2010. Kista ovarium, jakarta : FKUI

UPTD Puskesmas padang serai. 2016. Profil Data Penyakit Kista Ovarium, Kota Bengkulu

Winkjosastro. 2009. Asuhan kebidanan pada
Kehamilan Fisiologi, Jogyakarta ; Mitra Cendika

WHO. 2015. Profil Data Kesehatan Penyakit Kista, Jurnal

Yuan et-al. 2014. Kenali Kista Sejak Dini, Jakarta : Pustaka 